\title{
A VERDADE COMO DIREITO FUNDAMENTAL EM FACE DOS ATOS DE SEQUESTRO, TORTURA, MORTE E DESAPARECIMENTO DE PESSOAS NO REGIME MILITAR BRASILEIRO
}

\author{
ROGÉRIO GESTA LEAL ${ }^{1}$
}

\begin{abstract}
RESUMO: Pretendo neste ensaio tratar do tema da Verdade enquanto Direito Fundamental envolvendo os fatos ocorridos com o desaparecimento, morte, sequestro e tortura no âmbito do regime militar no Brasil ao longo das décadas de 1960 a 1980.

PALAVRAS-CHAVE: Verdade; Direitos Humanos; Direitos Fundamentais.
\end{abstract}

\begin{abstract}
I intend in this essay address the issue of Truth as a Fundamental Right evolving the events surrounding the disappearance, death, kidnapping and torture under the military regime in Brazil over the decades from 1960 to 1980. KEYWORDS: Truth; Human Rights; Fundamental Rights.
\end{abstract}

\begin{abstract}
SUMÁRIO: Notas Introdutórias; I Fundamentos Políticos e Jurídicos da Verdade enquanto Direito Fundamental Individual e Social; II Qual Verdade: aspectos conceituais preliminares; III As Comissões da Verdade na América Latina: algumas lições; IV O Segredo de Estado como barreira de Acesso à Verdade e sua Necessária Superação; Considerações Finais; Bibliografia.

SUMMARY: Introductory Notes; I Political and Legal Foundations of Truth as a Individual and Social Fundamental Right; II What Truth: conceptual preliminaries; III Truth Commissions in Latin America: some lessons; IV The Secret of State as a barrier to Access to the Truth and go Beyond; Final Considerations; Bibliography.
\end{abstract}

Artigo recebido em 13.08.2011. Pareceres emitidos em 29.01.2012 e 31.01.2012.

Artigo aceito para publicação em 12.03.2012.

${ }^{1}$ Desembargador do Tribunal de Justiça do Estado do Rio Grande do Sul, Doutor em Direito, Professor Titular da Universidade de Santa Cruz do Sul - RS. Professor da Universidade do Oeste de Santa Catarina - Campus Chapecó, SC. Professor Visitante da Università Túlio Ascarelli - Roma Trè, Universidad de La Coruña - Espanha, e Universidad de Buenos Aires. Professor da Escola Nacional de Formação e Aperfeiçoamento da Magistratura - ENFAM. Membro da Rede de Direitos Fundamentais - REDIR, do Conselho Nacional de Justiça - CNJ, Brasília. Coordenador Científico do Núcleo de Pesquisa Judiciária, da Escola Nacional de Formação e Aperfeiçoamento da Magistratura - ENFAM, Brasília. Membro do Conselho Científico do Observatório da Justiça Brasileira. Coordenador do Comitê de Gestão da Rede dos Observatórios do Direito à Verdade, Memória e Justiça nas Universidades Brasileiras, junto à Secretaria de Direitos Humanos da Presidência da República. gestaleal@gmail.com 


\section{NOTAS INTRODUTÓRIAS}

Pretendo neste ensaio tratar do tema da Verdade enquanto Direito Fundamental envolvendo os fatos ocorridos com o desaparecimento, morte, sequestro e tortura no âmbito do regime militar no Brasil ao longo das décadas de 1960 a 1980, em especial no que tange às particularidades políticas e jurídicas que envolvem a matéria.

I FUNDAMENTOS POLÍTICOS E JURÍDICOS DA VERDADE ENQUANTO DIREITO FUNDAMENTAL INDIVIDUAL E SOCIAL

Antes de adentrar no mérito propriamente dito do tema proposto aqui, como relevante perquirir sobre as razões de justificação e fundamentação que sustentam a ideia de Verdade envolvendo os fatos atinentes à tortura, sequestro, morte e desaparecimento de pessoas, como Direito Fundamental Individual e Social. Para tanto, quero me valer de algumas contribuições teóricas eleitas no campo da teoria política e da teoria jurídica.

Ronald Dworkin, importante filósofo do direito contemporâneo e professor catedrático da Universidade de New York, lançou em 2006 um texto chamado Is Democracy possible here?, discutindo uma série de questões, dentre as quais, terrorismo e Direitos Humanos, religião e dignidade, impostos e legitimação e, finalmente, o último artigo trata do tema das condições e possibilidades da Democracia em seu país. ${ }^{2}$

Tendo por cenário de fundo as discussões que se davam entre liberais e conservadores envolvendo o governo Bush (filho), e as radicalizações de posturas ideologicamente postas de cada qual, Dworkin chama a atenção para o fato de que os interesses da comunidade estão sendo cada vez mais deixados de lado, até porque, nos EUA, o interesse de ambos os principais partidos eleitorais vem sendo o de: how to win a majority, if only barely, in what was presumed to be a closely split and highly polarized electorate. ${ }^{3}$

O efeito no eleitorado disto é que ele não sabe diferenciar com nitidez o que distingue a proposta dos partidos e candidatos, uma vez que estão bombardeados por ações de comunicação, propaganda e publicidade voltadas à conquista do voto, independentemente de sua qualidade ou fundamento. É interessante como tais situações vão gerando, por sua vez, a univocidade identitária artificial e casuística do fenômeno político, fragilizando as posturas entre esquerda e direita, por exemplo, e colocando todos os atores da arena política como que compromissados com as mesmas demandas sociais (que também sofrem homogeneização forçada, e passam a ser de todos).

Sustenta o autor americano, nesta linha de raciocínio, que o tema dos Direitos Fundamentais hoje - mesmo nos EUA - carece de uma preocupação

\footnotetext{
${ }^{2}$ DWORKIN, Ronald. Is Democracy Possible Here? Principles for a New Political Debate. Princeton: Princeton University Press, 2006.

${ }^{3}$ STARR, Paul. Liberalism for Now. In www.nybooks.com/articles, Volume 56, no 12 , jul. de 2009, acessado em 10.02.2010, p. 02.
} 
cívica importante, notadamente em face dos poderes instituídos, e mais especialmente no âmbito parlamentar, eis que os legisladores em regra tratam destes pontos com níveis de ambiguidade e falta de decisão muito grande. ${ }^{4}$

Esquece-se desta forma que a verdade é a melhor referência que se pode ter para tratar disto tudo, todavia, na realidade americana, ela parece estar obsoleta, pelo fato de que: politicians never seek accuracy in describing their own records or their opponents'positions. ${ }^{5}$ Em verdade, o sistema político baseado na lógica do mercado transforma-se em mais um produto de consumo caro e acessível somente aqueles que têm condições de financiá-lo. Tal financiamento, todavia, representa mais do que acesso, mas controle do sistema político, em outros termos, in politics money is the enemy not just of fairness but of real argument. ${ }^{6}$

Por tais razões e outras sustenta - e com ele concordo - que o critério majoritário da deliberação política não é o único nem o mais importante na experiência Ocidental, eis que, muitas vezes, a vontade das maiorias não garante resultados justos e mais eficientes ao interesse público (que não é só o majoritário), gerando vários níveis de injustiça às minorias - ou mesmo ignorando demandas de minorias. Em face disto, caberia a pergunta: Quais os níveis de injustiça que uma Democracia suporta?

Dessume-se, pois, que o modelo de Democracia opera com a ideia de que ela significa o governo de cidadãos que estão envolvidos como grandes parceiros numa empreitada política coletiva, no qual as decisões democráticas só o são na medida em que certas condições estão presentes para os fins de proteger o status e os interesses de cada cidadão e de todos.

No campo da pragmática e do cotidiano, o que se pode perceber é a significativa falta de interesse pelos temas políticos e sociais, eis que mesmo os relacionados a direitos civis são objeto de manejo muito mais para o atendimento de interesses privados do que públicos, e na perspectiva majoritária isto se agrava ainda mais, na medida em que as deliberações políticas só levam em conta quem participa e como participam no plano formal do processo político, ou seja, democracy is only about how political opinions are now distributed in the community, not how those opinions came to be formed. ${ }^{7}$

Dworkin lembra que no modelo da democracia como conjunto de parceiros a perspectiva se diferencia, fundamentalmente porque opera com

\footnotetext{
${ }^{4}$ DWORKIN, Ronald. Is Democracy Possible Here? Op.cit., p. 129. O autor faz menção a eleição de 2004, nos EUA, em que foram feitas várias pesquisas para aferir o interesse e o conhecimento do povo americano sobre temas internacionais envolvendo seu pais, e eles nada sabiam disto. Esta lógica de fazer política vai contaminando o processo político como um todo, criando verdadeiros vícios em espiral (vicios spiral winds) de formação e percepção da política, afastando a cidadania do seu epicentro.

${ }^{5}$ Idem, p. 129.

${ }^{6}$ Idem.

${ }^{7}$ Idem, p. 132.
}

DiREITOS FundAMENTAIS E JUSTIÇA - ANO 6, N' 18, P. 203-228, JAN./MAR. 2012 
a lógica da mutua atenção e respeito enquanto essência desta matriz, sabendo que igualmente isto não faz parte das tradições e hábitos americanos, principalmente no cotidiano das pessoas e em suas relações com as outras. Registra o autor que: We do not treat someone with whom we disagree as a partner - we treat him as an enemy or at best as an obstacle when we make no effort either to understand the force of his contrary views or to develop our own opinions in a way that makes them responsive to his. ${ }^{8}$

Claro que em tempos de guerra e desconfianças mutuas as possibilidades de tratamento do outro com respeito se afiguram escassas, 0 que não justifica a paralisia diante de situações que reclamam mudança cultural, política, estrutural e funcional, sob pena de comprometimento não somente das relações intersubjetivas, mas das próprias relações institucionais em face da Sociedade.

Em verdade, e é o próprio autor que diz isto, a concepção majoritária de democracia não leva em conta outras dimensões da moralidade política resultando daí que uma decisão pode ser democrática sem ser justa -, enquanto que na perspectiva da democracia entre parceiros estão presentes outras considerações que meramente as processuais/formais, reclamando uma verdadeira teory of equal partnership, na qual se precisa consultar questões como justiça, igualdade e liberdade de todos os envolvidos. So on the parthership conception, democracy is a substantive, not a merely procedural ideal. ${ }^{9}$

Também não resolve ter-se um super-ativismo por parte da sociedade civil na direção de propugnar por uma democracia que venha a produzir decisões políticas substanciais de preferências seletivas majoritárias, porque novamente interesses contra-majoritarios podem ser violados de forma antidemocrática, exatamente em nome das deliberações formais majoritárias.

Desta forma, a regra majoritária de deliberação política - divorciada de uma opinião pública qualificada por seus argumentos - não assegura maiores níveis de legitimação do que deliberações monocráticas decorrentes de processos de consulta ou discussão pública efetiva. Falha inclusive aqui o chamado Teorema de Condorcet, para o qual a soma quantitativa majoritária das escolhas individuais homogêneas maximiza a chance de que se chegará a resultados democráticos e satisfativos, pois se teria de perguntar: satisfativo para quem? No mínimo - e nem isto está garantido para aquela maior parte quantitativa de indivíduos. ${ }^{10}$

Mesmo a perspectiva de que a regra das escolhas e deliberações majoritárias venham a estabelecer vínculos políticos e institucionais (com parlamentares e partidos), independentemente da forma constitutiva das escolhas/deliberações, não garante tratamento isonômico às escolhas e

\footnotetext{
${ }^{8}$ Idem.

${ }^{9}$ Idem.

${ }^{10}$ Idem, p. 140.
} 
pretensões contra-majoritárias. Como lembra Dworkin, os temas que envolvem políticas públicas apresentam não raro fundamentos morais de alta complexidade, not strategies about how to please most people. ${ }^{11}$

Outro ponto polêmico nesta discussão - e bem abordado por Dworkin diz com a compatibilidade, ou não, da existência de direitos individuais que não possam ser submetidos à vontade das maiorias, isto porque uma compreensão mais cidadã da ordem constitucional republicana e democrática impõe o que o autor americano chama de partnership conception, a qual requires some guarantee that the majority will not impose its will in these matters. ${ }^{12}$

Poder-se-ia questionar, neste sentido e em face do debate contemporâneo no Brasil, a possibilidade ou não da Conferência Nacional dos Bispos do Brasil - CNBB participar, na condição de amicus curiae ("amigo da corte"), nos processos que discutem a constitucionalidade do reconhecimento judicial da união estável homoafetiva - ADPF 132 e ADIN 4277, julgadas conjuntamente, sob a relatoria do ministro Carlos Ayres Britto -, no Supremo Tribunal Federal ${ }^{13}$, considerando que o ministro Marco Aurélio, relator da ADPF 54, em que se discute a constitucionalidade do chamado aborto de anencéfalos, nominada na inicial como antecipação terapêutica do parto, indeferiu o ingresso da CNBB, sob o fundamento, dentre outros, de que o Estado é laico.

Pergunta-se: Fundamentos religiosos poderiam ser considerados pelo Poder Judiciário e, portanto, pelo Supremo Tribunal Federal, na tomada de suas decisões? Ou somente a racionalidade laica pode sê-lo, sob pena de se impor valores religiosos oriundos de dogmas tidos como indiscutíveis pelas religiões respectivas a pessoas que não compartilham deles? Estes pré-conceitos religiosos poderiam ser aceitos no plano da racionalidade emancipada e democrática, que possibilita inclusive a não concordância e aceitação de tais argumentos por alguns?

Nas decisões das ações constitucionais acima referidas os ministros Marco Aurélio e Celso de Mello ressaltaram que o caráter laico do Estado impede que a moral religiosa sirva de parâmetro para limitar a liberdade das pessoas. Em seu voto, o Min. Marco Aurélio destacou o papel contramajoritário do Supremo - fazendo inclusive referência à decisão tomada em relação à Lei da Ficha Limpa -, ao lembrar que as normas constitucionais de nada valeriam se fossem lidas em conformidade com a opinião pública dominante.

\footnotetext{
${ }^{11}$ Idem, p. 141.

12 Idem, p. 146. Diz ainda o autor: On the partnership conception, therefore, constitutional rights protecting an individual's freedom to make ethical choices for himself are not compromises of democracy but rather attempts to guarantee it.

${ }^{13}$ O Supremo Tribunal Federal decidiu, de forma unânime, no dia 05.05.2011, estas Ações Constitucionais, equiparando as relações entre pessoas do mesmo sexo às uniões estáveis entre homens e mulheres, e com isto, reconhecendo estas relações como núcleo familiar.
} 
Aqui entra o tema do Direito Fundamental ao acesso as informações, dados e pessoas envolvidas - como vítimas ou algozes - nos atos de força do regime militar brasileiro, pois se trata, primeiro, de condição de possibilidade destas vítimas e seus familiares saberem por que causas e como ocorreram estes fatos (Direitos Fundamentais Individuais); segundo, da Sociedade ter tal informação para os fins de compromissar-se para com temas que são configurados como atentatórios à vida e dignidade humanas, e como matéria de lesa humanidade, independentemente de quem atinja, agrade ou desagrade (Direitos Fundamentais Sociais).

\section{QUAL VERDADE: ASPECTOS CONCEITUAIS PRELIMINARES}

Em documento oficial, a Comissão de Direitos Humanos das Nações Unidas, através de seu Alto Comissionado, desenvolveu um interessante estudo no ano de 2006 sobre a importância das comissões de verdade à democracia e aos Direitos Fundamentais, realçando uma série de elementos constitutivos dos fundamentos de tal demanda. ${ }^{14} \mathrm{Em}$ tal documento, se tem a noção originária deste conceito de verdade, no sentido de que este concepto tiene sus raíces en el derecho internacional humanitario, particularmente en lo que se refiere al derecho de los familiares a conocer la suerte de las víctimas, y en la obligación de las partes en conflictos armados de buscar a los desaparecidos. ${ }^{15}$

Pode-se dizer que esta verdade de que estou falando faz parte do Direito Internacional humanitário, eis que codificado explicitamente nos termos do art. 32, do Protocolo adicional aos Convênios de Genebra, de 12.08.1949 (Protocolo I), incorporando várias disposições que impõem às partes beligerantes a obrigação de resolver o problema dos combatentes desaparecidos e estabelecer um organismo central da busca destas pessoas.

Veja-se que, com a aparição da prática de desaparecimento forçado de pessoas nos regimes militares das décadas de 1960 e 1970 em diante, em especial na América Latina, o conceito de direito à verdade converteu-se em centro de debate importante por parte dos órgãos internacionais e regionais de Direitos Humanos, gerando inclusive Grupo de Trabalho ad hoc junto à Corte Interamericana de Direitos Humanos para os fins de analisar as violações de direitos no Chile, chamado Grupo de Trabajo sobre las Desapariciones Forzadas o Involuntarias, que, com a Comissão Interamericana de Direitos Humanos, criou sensível doutrina sobre a matéria, com base nos termos dos arts. 32 e 33, do Protocolo I, dos Convênios de Genebra referidos. ${ }^{16}$

\footnotetext{
${ }^{14}$ NACIONES UNIDAS. COMISIÓN DE DERECHOS HUMANOS. Promoción y Protección de los Derechos Humanos. Estudio sobre el Derecho a la Verdad. In E/CN.4/2006/91, 09 de enero de 2006, $62^{\circ}$ período de sesiones. Tema 17 del programa provisional, 2006.

${ }^{15}$ Idem, p. 04.

${ }^{16}$ Ver o texto de MÉNDEZ, Juan. Accountability for Past Abuses. In Human Rights Quarterly, vol. 19, n² 2, May 1997, pp. 255.
} 
Não se restringiu o tema da verdade ao desaparecimento forçado de pessoas, mas ampliou-se progressivamente para outras violações graves de Direitos Humanos e Fundamentais, como execuções de pessoas, tortura, sequestro, etc.

Houve desde a segunda década do século $X X$ várias conferências intergovernamentais como a Conferência Mundial contra o Racismo, a Discriminação Racial, a Xenofobia e as Formas Conexas de Intolerância, as quais também geraram declarações em que se afirma a importância de ensinar os fatos e a verdade da história, a fim de se chegar a conhecer de maneira ampla e objetiva as tragédias do passado.

A própria Assembléia Geral das Nações Unidas tem tratado de questões como o Direito à Verdade em diversas resoluções aprovadas desde 1974 em face das pessoas desaparecidas vítimas de regimes ditatoriais, daí exsurgindo o desejo de saber como uma necessidade humana básica. ${ }^{17}$

Importa dar destaque à XXVIII Cumbre de Chefes de Estado, celebrada em Assunção, Paraguai, em junho de 2005, quando os Estados Membros e associados do Mercado Comum do Sul (MERCOSUL) adotaram uma declaração na qual se reafirmava o Direito à Verdade das vítimas de violações dos Direitos Humanos e seus familiares. ${ }^{18}$

Na mesma direção foi o chamado acordo marco general de paz na Bosnia y Herzegovina de 2004, em decorrência da aprovação de uma lei no Parlamento desta comunidade sobre pessoas desaparecidas, reafirmando o direito das famílias a conhecer a sorte de seus membros desaparecidos. ${ }^{19}$

Em alguns países nos quais o Poder Executivo ou o Legislativo não tomaram providências sobre o tema sob comento, o Poder Judiciário o fez, como os Tribunais Constitucionais da Colômbia, Peru, os tribunais penais da Argentina, e outros, que asseguraram às pessoas o direito de acessar informações sobre seus próprios atingidos pelas violações referidas. El Tribunal Europeo de Derechos Humanos no ha tratado la cuestión del derecho a conocer la verdad explícitamente, pero lo ha inferido en el marco del derecho a no sufrir torturas o malos tratos, el derecho a un recurso efectivo y el derecho a una investigación eficaz y a ser informado sobre los resultados. ${ }^{20}$

\footnotetext{
17 Conforme HAYNER, Priscilla. Unspeakable Truths: Confronting State Terror and Atrocity. New York: Routledge, 2008.

${ }^{18}$ In Comunicado conjunto de los Presidentes de los Estados partes del MERCOSUR y de los Estados asociados, Asunción (Paraguay), 20 June 2005. In http://www.mercosur.int/msweb/ Documentos/Publicados/Comunicaciones, acessado em 03.06.2011.

${ }^{19}$ NACIONES UNIDAS. COMISIÓN DE DERECHOS HUMANOS. Promoción y Protección de Ios Derechos Humanos. Estudio sobre el Derecho a la Verdad. Op. cit., p. 62.

${ }^{20}$ NACIONES UNIDAS. COMISIÓN DE DERECHOS HUMANOS. Promoción y Protección de Ios Derechos Humanos. Estudio sobre el Derecho a la Verdad. Op. cit., p. 09. Aqui há o registro de que: El Tribunal Constitucional del Perú ha determinado que el derecho a la verdad es una expresión concreta de los principios constitucionales de la dignidad humana, el estado de derecho y el sistema de gobierno democrático.
} 
A Corte Interamericana de Direitos Humanos tem historicamente reconhecido o direito dos familiares - ou seus representantes - das vítimas de desaparecidos, mortos e sequestrados a saberem seus paradeiros, obtendo assim uma explicação dos fatos ocorridos, haja vista inclusive os níveis de responsabilidades que a Convenção Americana sobre Direitos Humanos atribui ao Estado, seja pela via da garantia do direito de ser ouvido por um Tribunal competente, independente e imparcial (art. $8^{\circ}$ ), seja pelo direito a um recurso efetivo e à proteção judicial (art.25), do que se dessume a necessidade deste Estado levar adiante uma investigação eficaz das violações. ${ }^{21}$

Como já disse alhures, as várias possibilidades de debate sobre violações de Direitos Humanos e Fundamentais decorrentes de estados de exceção encontram múltiplos espaços interculturais de abordagem, dentre os quais o da justiça de transição. Neste particular, pode-se dizer que o evolver do chamado modelo restaurativo da justiça transicional trouxe valiosas contribuições à ampliação de enfoque destes cenários, para além das persecuções penais dos agentes públicos e de responsabilidade patrimonial direta às vítimas dos atos de terror de Estado (tortura, sequestro, morte e desaparecimento de pessoas). ${ }^{22}$ Mas o que pretende de novo este modelo?

O centro neural de ocupação da justiça transicional é exatamente o de fomentar o confronto entre justiça e verdade, dando relevo à investigação, documentação e divulgação pública dos abusos e violações de Direitos Humanos e Fundamentais em regimes de força, visando em especial a formatação de uma memória didática e pedagógica compromissada à pacificação e reconciliação, portanto, pró-ativa, geradora de políticas públicas que vão além da reparação e punição, mas apostam na necessária configuração da opinião pública, de uma identidade democrática promocional e do aprendizado republicano. Na dicção dos Princípios de Chicago referentes à Justiça de Transição: Los Estados deberían integrar la documentación y el análisis de esas violaciones en los programas de enseñanza nacional. Los Estados deben trabajar con las víctimas, las comunicaciones, las organizaciones de la sociedad civil y otras a fin de prevenir su repetición y se logre crear una cultura de respeto de los derechos humanos y el Estado de Derecho. ${ }^{23}$

E como se faz isto?

\footnotetext{
${ }^{21}$ Conforme ANNUAL REPORTS OF IACHR, 1985-1986, p. 205; and 1987-1988, p. 359. É preciso reconhecer que no âmbito desta eficiência da resposta Estatal, a questão de se o direito à verdade inclui o conhecimento da identidade dos autores das violações é um tema polêmico ainda mais forte. Todavia, a posição do Comitê de Direitos Humanos, da Comissão Interna de Direitos Humanos e da Corte Interamericana de Direitos é no sentido de que isto é possível sim.

${ }^{22}$ Neste sentido a reflexão de HAYNER, Priscila B. Unspeakable Truths: Confronting State Terror and Atrocity. Op. cit.

${ }_{23}$ INSTITUTE. International Human Rights Law. Los Principios de Chicago sobre Justicia transicional. In http://www.iidh.ed.cr/bibliotecadigital, acesso em 29.01.2011, p. 77.
} 
A recente história ocidental já consolidou algumas experiências exitosas neste sentido, em especial, a Comissão Nunca Más, da Argentina, na década de 1980, e a Comissão da Verdade e Reconciliação da África do Sul, na década de 1990, ambas com formatos e metodologias de trabalho distintos, mas convergindo na busca de informações, documentos, corpos e pessoas que pudessem restaurar e reparar os fatos ocorridos, para que servissem ao propósito de radicalizar a opção pela Democracia.

A estratégia fundamental para esta discussão não se centra no âmbito exclusivo ou prioritário da responsabilidade de pessoas por atos de tortura, sequestro, morte e desaparecimento de cidadãos brasileiros no regime militar - aspectos de natureza mais penal -, mas sim na do próprio Estado e Governo enquanto promovedores de políticas públicas revitalizadoras do regime democrático. ${ }^{24} \mathrm{E}$ isto também porque las transiciones presentan un dilema de determinación de mínimos. Por definición éstas son épocas de disputas en torno a narrativas históricas. Así, las transiciones presentan el potencial para la creación de contra-historias. ${ }^{25}$

Em verdade, nas democracias mais frágeis, nas quais a administração de sanções e castigos a indivíduos podem provocar dilemas e desconfortos corporativos e institucionais, estes âmbitos precisam ser dissociados do tema da Verdade, sob pena de colocar em xeque temas de naturezas e importâncias diversas. Por tais razões é que muitos países resolveram de certa forma renunciar as persecuções penais e, ou, distingui-las do papel das Comissões da Verdade, exatamente para viabilizar processos de transição pacificadores, indispensáveis inclusive à recuperação do que se pode chamar de identidade política da Democracia e do Estado de Direito. ${ }^{26}$

Assim, a busca da verdade em tais situações está mais fundada no que se pode chamar de teorias do perdão e da reconciliação, cujo foco não é tanto a justiça enquanto resultado da jurisdição, mas a pacificação emancipadora e crítica da sociedade civil como um todo, e isto porque, se na maioria das vezes a paz é simplesmente a ausência de guerra, após esta há dimensões e âmbitos de direitos violados que se propagam espacial e temporalmente, demandando níveis mais profundos de pacificação, criando

\footnotetext{
${ }^{24} \mathrm{O}$ que é bem lembrado por TEITEL, Ruti G. Genealogía de la Justicia Transicional. In http://www.iidh.ed.cr/bibliotecadigital, acesso em 29.01.2011, p. 09. Esclarece a autora que: El intento de hacer valer la responsabilidad en los hechos por medio del derecho penal, a menudo generó dilemas proprios del estado de derecho, incluyendo la retroactividad de la ley, la alteración y manipulación indebida de leyes existentes, un alto grado de selectividad en el sometimiento a proceso y un poder judicial sin suficiente autonomía.

25 PÁEZ, D.; VALENCIA, J.; PENNEBAKER, J.; RIMÉ, B.; JODELET, D. (EDS); Memoria Colectiva de Procesos Culturales y Políticos. Editorial de la Universidad del País Vasco/Euskal Herriko Unibertsitatea, Leioa, 1997, p. 62.

${ }^{26}$ Como diz Hannah Arendt, el examen genealógico, interdisciplinario y comparativo de los regimes de força revelan altamente divergentes concepciones del estado de derecho, que a su vez reflejan perspectivas legales y culturales diferentes. In ARENDT, Hannah. De la historia a la acción. Barcelona: Paidós, 1995, p. 76.
} 
bases de desenvolvimento cognitivo e informacional que sirvam como ferramentas à sensibilização social para o que não pode se repetir. ${ }^{27}$

Ocorre que qualquer reconciliação sobre estes temas se afigura como de alta complexidade, pois envolve procedimentos e estratégias de interlocuções muitas vezes tensas e conflitantes, eis que deve atingir a todo mundo, não só aquelas pessoas que sofreram diretamente ou que perpetraram os atos violentos, implicando mudança de atitudes, expectativas, emoções e crenças sociais, inexistindo receitas prontas e únicas para lograr êxito. ${ }^{28}$

Apresenta-se sensata, neste diapasão, a advertência de Alexandra de Brito, no sentido de que a revelação da verdade quanto a justiça pode ser problemática, eis que:

Elas podem ser catárticas, mas também podem perpetuar conflitos. Podem criar uma mentalidade 'nós contra eles', perpetuando o conflito social, como no 'jogo sem fim' descrito por Malamud-Goti. O poder judicial pode servir a um fim imoral, e os tribunais democráticos podem perpetuar um ciclo de vingança e culpa; mas podem também atuar como uma espécie de "teatro político", educando o povo sobre o valor da lei e da justiça. Por vezes, não fica claro qual destas lógicas ganha. Constrangimentos financeiros, políticos, pessoais e de tempo, assim como dificuldades em acessar à informações significam que tanto os julgamentos quanto as comissões da verdade serão seletivas no quadro que constroem e na justiça que concretizam. $E$, como Offe observa sobre o caso pós-comunista na Alemanha, "o máximo que pode possivelmente ser feito dentro das limitações do Estado de Direito e da não-retroatividade está muito abaixo do mínimo que teria de ser feito para reconciliar os pequenos, porém vocais, grupos daqueles que sofreram mais sob o antigo regime". ${ }^{29}$

Para que uma reconciliação seja duradoura, alguns aspectos são destacados pela doutrina internacional: (a) deverão ocorrer mudanças de atitudes, condutas e entorno institucional que o possibilite; (b) é necessário uma interpretação compreensiva dos acordos de paz, pois se para alguns se trata somente de chegar a um acordo entre as partes, para outros é uma maneira de buscar a governabilidade de uma região, desativando o conflito armado.

\footnotetext{
${ }^{27}$ Estou me valendo aqui das reflexões de KISS, Elizabeth. Moral Ambitions Within and Beyond Political Constraint: reflexions on restorative justice. New York: Lendell, 2007. Ver também o texto de O'DONNELL, Guillermo; SCHMITTER, Paul; WHITEHEAD, Louis (eds.). Transitions from Authoritarian Rule. 4 Vols., Baltimore: Johns Hopkins University Press, 1986.

${ }^{28}$ É interessante a tese de que é extremamente importante, enquanto política pública de integração social, que os perpetradores sejam reinseridos na sociedade, sob pena de, havendo sua exclusão, ficar ameaçada a integração e reconciliação da sociedade. In INSTITUTO DE DERECHOS HUMANOS DE LA UNIVERSIDAD CENTROAMERICANA JOSÉ SIMEÓN CAÑAS. La agenda pendiente, diez años después (de la esperanza inicial a las responsabilidades compartidas). El Salvador: UCA, noviembre de 2002, pp. 25 a 99.

${ }^{29}$ BRITO, Alexandra Barahona de. A Justiça Transicional e a Política da Memória: uma visão global. In Revista Anistia, vol. I, Brasília: Ministério da Justiça, 2009, p. 73.
} 
Desta forma, são etapas do processo de negociação: trocar medo por coexistência não violenta - redução gradual da tensão a partir da cessação das hostilidades, iniciando um processo de comunicação entre os grupos; construção da confiança entre os grupos em conflito; favorecer a empatia e promover mudanças substanciais - necessidade de medidas que aborde o impacto do sofrimento, a memória coletiva e as formas de colaboração no presente, o que é feito pelas comissões da verdade. ${ }^{30}$

Os próprios projetos de anistia ganham outra dimensão nesta perspectiva, pois não estão centrados tanto no âmbito dos indultos penais envolvendo atos tipificados como criminosos e passíveis de sanção, ou mesmo nas reparações pecuniárias que sempre correm o risco de mercantilizar a discussão ${ }^{31}$, mas se focam em estratégias de adesão social e fomento à participação espontânea dos envolvidos naqueles episódios.

A experiência africana é muito rica aqui, na medida em que tratou destes temas pós-ditaduras com sensibilidade e espírito reconciliador, alterando a lógica à apuração da verdade e memória, valorizando sobremaneira as narrativas pessoais dos envolvidos - vítimas e algozes -, através de sua Truth and Reconciliation Comission - TRC, e incentivando procedimentos especiais de confissão e desculpa. Nestes termos, todas as pessoas que confessassem estórias de tortura, abusos, ocultação de cadáveres, e outros crimes da repressão, perante a TRC, receberiam o indulto, gerando massivos comportamentos de auto-responsabilização sem a presença impositiva e dura do Estado Democrático na condição de julgador. ${ }^{32}$ É o que também sustenta Andrè du Toit: las concepciones morales constitutivas de "verdad y reconciliación" pueden ser explicadas más específicamente en términos de verdad como reconocimiento y justicia como recognition y que éstas pueden, en principio, proporcionar uma alternativa coherente, a lo menos en circunstancias de justicia transicional, a las nociones retributivas de justicia que requieren procesamiento y castigo penal. ${ }^{33}$

\footnotetext{
${ }^{30}$ Idem.

${ }^{31}$ Vale aqui a advertência que faz sobre o tema o médico psiquiatra chileno Carlos Madariaga, ao dizer que: existe un confusionismo conceptual respecto a lo que se entiende por reparación de manera reduccionista, privilegiando las soluciones pecuniarias, en desmedro de los aspectos juridicos, éticos, sociopolíticos y psicosociales, hecho que ha generado en las víctimas fuertes sentimientos de frustación y desencanto, estados psicoemocionales que han hecho abortar en gran medida los esfuerzos de reparación en curso. MADARIAGA, Carlos. La Reparación por parte del Estado hacia las víctimas de la Tortura. In Revista Reflexión, año 7, n 22. Diciembro de 1994. Santiago: Chile, p. 08.

${ }^{32}$ ASMAL, Kader. International Law and Practice: dealing whit the past in the South African experience. In International Law Review, vol. 15, $n^{\circ} 06$, November/2000, p. 1215. Lembra o autor que as anistias foram muitas vezes a condição de possibilidade para que se estabelecessem Comissões da Verdade e da Memória em diversos países, inclusive na África do Sul.

${ }_{33}$ TOIT, Andrè du. Los Fundamentos Morales de las Comisiones de Verdad la Verdad como Reconocimiento y la Justicia como Recognition: Principios de la Justicia Transicional en la Práctica de la Comisión de Verdad y Reconciliación (CVR) Sudafricana. Centro de Derechos Humanos, Facultad de Derecho, Universidad de Chile, 2008, p.03. Ver também o texto de
} 
É perceptível que ativistas de Direitos Humanos e mesmo a Academia, nesta quadra histórica, se ocuparam mais de ampliar o debate para além do jurídico e suas facetas criminais, alçando estes temas para níveis históricos e políticos, compreendendo tais conflitos em termos universais e atemporais. Como diz Dominic McGoldrick, o próprio direito ganha fôlego amplificador na apreensão destes problemas, construindo linguagens universalizadoras sobre o perdão e a possibilidade de redenção política envolvida na espécie. ${ }^{34}$

A ética da responsabilidade com o outro e as gerações presentes e futuras vê-se relevada nos conceitos de verdade que se operam aqui, oportunizando interconexões entre esfera pública e privada, na medida em que os atos de governo/Estado passam a interagir com os atos privados de pessoas que, ou foram atingidas, ou foram autoras de regimes de força autoritários (estou falando tanto dos agentes públicos como os indivíduos da resistência violenta que se criou em face de tais circunstâncias, e que perpetraram atos de sequestro, tortura, desaparecimento e morte de pessoas).

Assim é que com as Comissões da Verdade se busca conhecer as causas da violência ocorrida naqueles períodos, identificar os elementos em conflito, investigar melhor os fatos mais graves de violações aos Direitos Humanos, eis que muitos dos atingidos diretamente nos eventos sequer sabiam o que ocorria. Por outro lado, não se pode deixar de reconhecer que la acrobacia política permite que los gobiernos de transición atiendan, em cierta medida, las exigencias de justicia y de reconciliación, prefiriendo esta última, como garantía de estabilidad democrática. Por eso ponen más empeño en favorecer la impunidad de los violadores de los derechos humanos, volviendo a agredir así, en nombre de la reconciliación, a los familiares de las víctimas. ${ }^{35}$

De qualquer sorte é uma conquista do Direito Internacional e da Sociedade Civil o de SABER o que ocorreu com seus compatriotas nos chamados regimes militares, haja vista os vários Tratados, Pactos e Acordos Internacionais sobre o tema. Mas o que vem a ser este Direito de Saber?

Es el derecho imprescriptible a conocer la verdad acerca de las circunstancias en que se cometieron las violaciones y, en caso de fallecimiento o desaparición, acerca de la suerte que corrió la víctima".

DYZENHAUS, David. Judging the Judges, Judging Ourselves: Truth, Reconciliation and the Apartheid Legal Order, Oxford: Hart Publishing, 1998.

${ }^{34}$ MCGOLDRICK, Dominic. The Human Rights Committee -Its role in the development of the International Covenant on Civil and Political Rights. Oxford: Oxford University Press, 2006, p. 119 e seguintes. Ver o excelente texto de TAVUCHIS, Nicholas. Mea Culpa: a sociology of apology and reconciliation. Stanford: Stanford University Press, 2001.

${ }^{35}$ NACIONES UNIDAS, COMISIÓN DE DERECHOS HUMANOS. Informe del Alto Comisionado de las Naciones Unidas para los Derechos Humanos sobre la situación de los derechos humanos en Colombia, E/CN.4/2003/13, 24 de febrero de 2003, p. 23. Ver também o conjunto de princípios atualizado para a proteção e a promoção dos directos humanos mediante a luta contra a impunidade, conforme o documento E/CN.4/2005/102/Add.1. 
Las personas directa o indirectamente afectadas por un crimen internacional tienen derecho a saber siempre, aunque haya transcurrido mucho tiempo desde la fecha en la cual se cometió el ilícito, quién fue su autor, en qué fecha y lugar se perpetró, cómo se produjo y por qué llegó a ejecutarse. ${ }^{36}$

É interessante verificar agora algumas experiências na América Latina de constituição destas Comissões e suas metodologias de trabalho, o que passo a fazer. LIÇÕES

III AS COMISSÕES DA VERDADE NA AMÉRICA LATINA: ALGUMAS

Em vários países da América Latina os processos de saída dos regimes militares ao longo das décadas de 1960 a 1990 foram auxiliados por políticas públicas envolvendo a investigação das violações de Direitos Humanos e Fundamentais e as formas de reparação dos danos causados em face disto.

Uma das formas evidenciadoras destas políticas foram as Comissões da Verdade, com distintos aportes e finalidades, mas todas envolvidas em temas comuns decorrentes dos regimes de força e violência gestados pelos governos militares.

Tenho como interessante destacar as particularidades distintivas e convergentes de algumas experiências dos países vizinhos ao Brasil justamente para tentar maturar mais os caminhos e opções que se podem tomar nesta quadra histórica em que se vive.

A começar pela Argentina, pesquisas e documentos históricos estimam que cerca de 30.000 pessoas tiveram direitos violados, através de desaparecimento forçado e assassinato durante o regime militar. ${ }^{37}$

Tão logo assumiu o governo argentino, o Presidente Raúl Alfonsín criou a Comissão da Verdade, chamada de Comissão Nacional para a Investigação sobre o Desaparecimento de Pessoas (CONADEP), que tinha como objetivo investigar as violações ocorridas no período de 1976 a 1983. O período de investigação foi de nove meses. Composta por escritores, Bispos, Rabinos, Deputados, dentre outras pessoas, a CONADEP contava com 13 membros. Com as informações geradas por esta comissão a população argentina passou a conhecer a história das ocorrências do período militar.

Conforme a CONADEP avançava nas investigações, seus membros foram ameaçados por agentes da repressão, acusados de ativar o ódio e o ressentimento. A despeito disto, conseguiu produzir o documento Nunca Más, evidenciando: o desaparecimento de 8.960 pessoas durante o regime militar, e que esse número não era final, pois existiam outros casos que estavam em etapa de investigação; $80 \%$ dessas pessoas possuíam de

${ }^{36}$ Idem.

${ }^{37}$ NÜRNBERGER, Esteban Cuya. Las Comisiones de la verdad en América Latina. Disponível em: http://www.iidh.ed.cr/bibliotecadigital. Acesso em 29.01.2011, p.18. 
21 a 35 anos de idade; a existência de 340 centros clandestinos de detenção, onde os prisioneiros viviam em condições desumanas e sofrendo todo tipo de humilhações; que os oficiais das Forças Armadas tinham uma espécie de pacto de sangue, no qual todos participavam das violações a direitos humanos, sob pena de aquele que se recusasse tornar-se vítima; muitas pessoas foram exterminadas, com destruição de seus corpos, para evitar posterior identificação; uma lista com 1351 repressores, com seus nomes, incluindo juízes, médicos, bispos e sacerdotes; a existência de uma ilha, da Igreja Católica, que servia de campo de concentração. ${ }^{38}$

A CONADEP prestou as seguintes recomendações ao Estado argentino: (a) continuação das investigações na via judicial; (b) prestar assistência econômica, bolsas de estudo e trabalho aos familiares das vítimas; (c) aprovação de normas que estabeleçam o desaparecimento forçado como crime de lesa humanidade; (d) ensino obrigatório de direitos humanos nos centros de educação, tanto civis, como militares e policiais; (e) apoio a grupos de direitos humanos; (f) revogação da legislação repressiva existente no país. ${ }^{39}$

No Chile, o Presidente Patrício Aylwin Azocar criou, em 1990, a Comissão Nacional de Verdade e Reconciliação, tendo oito membros e prazo de nove meses para investigação. Esta Comissão tinha como funções as seguintes: (a) estabelecer um quadro sobre as violações aos direitos humanos, seus antecedentes e circunstâncias; (b) reunir informações para individualizar as vítimas e seus paradeiros; (c) recomendar as medidas de reparação e reivindicação necessárias; (d) recomendar as medidas legais e administrativas cabíveis.

Foram investigados os fatos ocorridos no período de 11 de setembro de 1973 a 11 de março de 1990, contando a Comissão com a colaboração de diversos organismos nacionais e internacionais de Direitos Humanos. Foram ouvidos mais de 3.400 familiares de desaparecidos, tendo ocorrido inclusive viagens internacionais a fim de ouvir o relato de exilados.

$\mathrm{Na}$ experiência chilena a Comissão da Verdade se valeu de uma rede significativa de colaboradores, desde Universidades e estudantes de direito (para a formulação das denúncias), até assistentes sociais - para auxílio aos familiares das vítimas, em razão da rememoração de todo o sofrimento. Importante o registro de que houve a colaboração das Forças Armadas, hospitais e Registro Civil, respondendo quase sempre que os documentos haviam sido incinerados ou destruídos em cumprimento a decisões judiciais.

O resultado das investigações da Comissão resultou em um Informativo, com as seguintes recomendações: (a) para a reparação pública da dignidade das vítimas; (b) à constituição de medidas de bem-estar social, pensão de

\footnotetext{
${ }^{38}$ In http://www.desaparecidos.org/arg/conadep/nuncamas/, acesso em 25.05.2011.

${ }^{39}$ Idem. 
reparação, atenção especial para a saúde, educação, condenação de dívidas e isenção da obrigatoriedade do Serviço Militar aos filhos das vítimas; (c) para que se providenciasse a declaração de morte das pessoas detidasdesaparecidas; (d) que fosse adequado o ordenamento jurídico nacional ao internacional de direitos humanos; (e) que fossem ratificados tratados internacionais sobre direitos humanos; $(f)$ que fosse dado continuidade às investigações sobre os fatos apurados. ${ }^{40}$

Em 1992 o governo do Chile criou a Corporação Nacional de Reparação e Reconciliação, para cumprir e executar as recomendações da Comissão da Verdade e Reconciliação.

Em El Salvador igualmente se constitui a Comissão da Verdade, composta de três membros, todos estrangeiros, com foco específico à pacificação nacional através de um acordo entabulado entre o governo e o movimento guerrilheiro Frente Farabúndo Martí para Liberación Nacional. A partir desse acordo, ambas as partes concordaram em criar uma comissão da verdade, para averiguar as violações a direitos humanos ocorridas no país desde 1980. A comissão teve seis meses para investigar e dois meses para elaborar o Informe De la loucura a la esperaza - la guerra de 12 años em El Salvador. ${ }^{41}$

Esta comissão investigou, num primeiro momento, as violações praticadas por agentes do Estado contra os opositores políticos, verificando o assassinato de seis sacerdotes jesuítas e diversas execuções extrajudiciais e assassinatos cometidos pelo esquadrão da morte. Depois, analisou a violência do FMLN contra opositores, recomendando, ao final, as seguintes providências: (a) a reforma da legislação penal e do Poder Judiciário; (b) providenciar inabilitações políticas por um prazo de, no mínimo, 10 anos, às pessoas envolvidas em violações a direitos humanos; (c) investigar e terminar com grupos ilegais (esquadrão da morte); (d) providenciar a reparação material e moral às vítimas e seus familiares direto; (e) providenciar a entrega de terras, equipamentos agropecuários, bolsas de estudo às vítimas e seus familiares. ${ }^{42}$

Na contramão da história, a experiência do Peru não teve o êxito das anteriores, isto porque as circunstâncias constitutivas de sua realidade foram muito distintas, em face, fundamentalmente, da guerra interna envolvendo o organizado movimento Sendero Luminoso. Esta guerra produziu cerca de 30.000 mortos e mais de 5.000 desaparecidos, sendo que por diversas vezes o Estado criou comissões da verdade para esclarecer as denúncias de graves violações a Direitos Humanos. Poucos registros dão conta de alguns resultados destas comissões de verdade: processos judiciais, como nos casos Fujimori e Guzmán; recuperação da independência do Poder Judiciário; programas de reparações, com mais de cem milhões de dólares,

\footnotetext{
${ }^{40}$ Idem, p.19.

${ }^{41}$ In http://www.uca.edu.sv/publica/idhuca/cv.pdf, acessado em 03.06.2011.

${ }^{42}$ In http://www.educabolivia.bo/educabolivia, acessado em 03.06.2011.
} 
inadmissão de anistias, prescrições e coisas julgadas envolvendo os autores de violações de direitos no regime de exceção. ${ }^{43}$

Em outros países da América Latina que viveram regimes ditatoriais e violentos, apesar de não se constituírem Comissões da Verdade, houve significativa mobilização da Sociedade Civil, como o caso da Bolívia, em que se criou uma Comissão Nacional de Desaparecidos pelo governo, mas que pouco investigou. Em face disto, criou-se, pelos familiares das vítimas e outros organismos, um Juízo de Responsabilidades, cujas denúncias, contudo, esbarraram no Congresso, que excluiu as investigações de fatos ocorridos antes do Golpe de García Meza. ${ }^{44}$

Quando o Congresso decidiu acusar o ex-ditador García Meza na Corte Suprema, fora expedida ordem de prisão, oportunidade em que o acusado se declarou em rebelião e se escondeu. A justiça determinou o confisco de suas propriedades e a perda dos direitos políticos. Mesmo na clandestinidade, García Meza ameaçava os grupos de Direitos Humanos e chantageava o governo para obter proteção em troca de seu silêncio, tendo sido preso mais tarde no Brasil. ${ }^{45}$

Foi criado pelo novo governo um Comitê do Juízo de Responsabilidades, que investigou e elaborou informativos, inclusive para a televisão, sobre as violações ocorridas durante o período militar, a partir do que várias pessoas do governo passaram a contribuir com as investigações, que acabaram revelando a forma que agia o governo militar, descobrindo-se que alguns membros do exército boliviano treinavam e dirigiam grupos paramilitares que cometiam atentados terroristas. Descobriram, também, a existência de uma lista negra, com nomes de pessoas envolvidas com movimentos de Direitos Humanos que deveriam ser eliminadas.

Em 1992, a Bolívia condenou os ex-ditadores García Meza e Luis Arce Gomes a 30 anos de prisão. Também foram condenados outros 50 envolvidos. É importante registrar que, apesar da comissão da verdade boliviana, chamada Comitê Promotor do Juízo de Responsabilidades não ter sido governamental, seus trabalhos foram muito eficazes, comprometendo a maior parte dos organismos do país na busca pela verdade.

No Paraguai o regime militar não foi diferente dos outros países, eis que, por 35 anos, o país ficou aterrorizado com as atitudes e ações do governo militar, tendo inclusive centralizado os arquivos do sistema de terrorismo dos países do Cone Sul da América, chamando de Operação Condor, com registros imensos sobre os movimentos de esquerda e comunistas em todo este território. ${ }^{46}$

\footnotetext{
${ }^{43}$ Revista "Oiga", "Informe sobre Uchuraccay", Lima, Perú, 7 de marzo de 1983, pág. 25 a 36.

${ }^{44}$ In http://www.bolpress.com/art.php?Cod=2009072206, acessado em 03.06.2011.

${ }^{45}$ Idem.

${ }^{46}$ Há notícias de que esta Operação Condor ainda existe, nominada hoje de Confederação dos Exércitos Americanos, reunindo altos dirigentes dos Exércitos da Bolívia, Brasil, Canadá, Chile, 
Em 1976 foi criado o Comitê de Igrejas para Ajudas de Emergência CIPAE, contando com o apoio de organismos internacionais, desenvolvendo um trabalho de pesquisa e catalogação de documentos de fatos de violência no país. Por razões óbvias, tomaram o cuidado de duplicar os documentos, pela técnica da microfilmagem, para não correrem o risco de perder ou de serem confiscados pelo regime militar. O resultado destas investigações foi publicado a partir de maio de 1990, em quatro tomos chamados: Paraguai: Nunca Mais. Nesse informativo há a indicação de que 360 mil pessoas passaram pelas prisões do ditador Stroessner e que 1,5 milhões de paraguaios foram obrigados a ir par o exílio. ${ }^{47}$

Contudo, de todos os casos denunciados, somente 16 receberam tratamento judicial, a despeito da lentidão dos processos e medidas.

No final de 1993 foram descobertos no Paraguai arquivos do sistema repressivo dos governos do Cone Sul da América, qualificados como Arquivos do Terror. Ali são encontrados documentos sobre as ocorrências na Bolívia, Uruguai, Argentina, Paraguai, Chile e Brasil. ${ }^{48}$

\section{O SEGREDO DE ESTADO COMO BARREIRA DE ACESSO À VERDADE E SUA NECESSÁRIA SUPERAÇÃO}

Ao lado desta história latino-americana envolvendo uma cultura de violência das forças de segurança pública em regimes militares, ainda se tem outro obstáculo ao acesso à verdade do ocorrido que é o que chamo de Segredo de Estado oponível a certos documentos, dados e informações referentes aqueles períodos.

Em termos políticos e administrativos houve tempo - não muito longínquo e quiçá ainda vigente em alguns territórios - em que a regra era o segredo enquanto ausência de informação e comunicação, viabilizando autoritarismos e regimes ditatoriais das mais diversas formas e modalidades - físicos, simbólicos, burocráticos, etc.

Alguns especialistas são mais incisivos nesta matéria e sustentam que os níveis de democracia da sociedade contemporânea dependem dos respectivos índices de difusão das informações em seu cotidiano, outorgando ao cidadão a possibilidade de conhecer o máximo de informações possíveis - sobre o espaço publico e privado -, resguardado, por certo, os direitos fundamentais de cada qual. Em especial no que diz com a coisa publica, tais

Colômbia, Equador, Estados Unidos, El Salvador, México, Nicarágua, Paraguai, Peru, República Dominicana e Uruguai, conforme noticiado em http://pbrasil.wordpress.com/2009/ 10/28/representantes-de-exercitos-americanos-se-reunem-na-argentina, acesso em 14.06.2011. Também ver a noticia em http://www.sgex.eb.mil.br/qgnoticias/qgex_352.pdf, acessada em 14.06.2011.

${ }^{47}$ É interessante a informação de que o governo dos EUA apoiou a ditadura paraguaia em troca de apoio na Guerra Fria, para combater o comunismo. In BORAINE, Alex. What price reconciliation? The achievement of the TRC. In A Country Unmasked. Oxford: Oxford University Press, 2000, pp. 340-378.

${ }^{48}$ Idem. 
informações se referem às leis, sentenças, disposições administrativas, circulares, e quaisquer outros documentos que se refiram a interesses subjetivos passíveis de publicação.

Com o advento da Constituição de 1988 no Brasil, restou claro, pelos termos conjugativos do art. 37, caput, e do art. 93, incisos IX e X, que são públicos os atos e negócios da Administração Pública no país, observadas as situações que envolvem segurança nacional ou congênere. Com maior grau de especificidade, pelos termos da Lei Federal no 9.784, de 29.01.1999, que regula os procedimentos administrativos, de igual sorte restaram consolidados direitos e garantias da cidadania - e da Administração - no atendimento de demandas, inclusive de informação, que se apresentam a esta.

Por tais razões se pode dizer, com Sandulli, que é regra constitucional do agir administrativo a sua transparência, eis que:

costituisce un'esigenza assolutamente fondamentale degli ordinamenti democratici, ponendosi come strumento indispensabile a realizzare un effettivo e diretto rapporto tra governanti e governati, per il fatto di consentire a questi ultimi una più consapevole partecipazione all'operato dei pubblici poteri e un più pieno controllo della relativa rispondenza agli interessi sociali e ai precetti legislativi e costituzionali. ${ }^{49}$

Mas em termos operacionais, o que significa esta transparência administrativa? Junto com a participação nos procedimentos administrativos, à motivação e publicidade dos atos administrativos, o darem a conhecer os documentos públicos, perfazem os elementos centrais de conceituação e significado da transparência na espécie.

Agora, em um ordenamento jurídico como o brasileiro, em que vige a exigência da documentação administrativa - decorrente dos princípios informativos do art. 37, caput, da Constituição Federal -, o direito de acesso constitui, se não o principal, certamente um dos parâmetros fundamentais para colocar à prova a maturidade do sistema como um todo e verificar a possibilidade de afirmar e concretizar esta centralidade que o cidadão possui no âmbito da gestão do interesse público. Assim, per definizione, accesso si contrappone a segretezza. II binomio implica un rapporto inversamente proporzionale tra i termini: minore è il grado di segretazione, maggiore è la possibilità di accedere ai documenti. ${ }^{50}$

\footnotetext{
${ }^{49}$ ROMANO, Santi. Principii di Diritto Amministrativo. Milano: Giuffrè, 1906. p. 22. Ainda refere o autor que: il diritto di accesso, ponendosi come momento di attuazione del principio di partecipazione e quale strumento di controllo dei cittadini sull'imparzialità della pubblica amministrazione, deve diventare come regola, generale ed immanente, dell'ordinamento giuridico italiano.

${ }^{50}$ ARENA, Gregório. II Segreto Amministrativo. Padova: CEDAM, 2004, p.34. Refere ainda o autor que: l'accesso ai documenti amministrativi, attese le sue rilevanti finalità di pubblico interesse, costituisce principio generale dell'attività amministrativa al fine di favorire la partecipazione e di assicurarne l'imparzialità e la trasparenza.
} 
Pode-se ainda, no mesmo texto constitucional, destacar algumas previsões normativas muito claras nesta direção, dentre as quais, no plano formal, tratando de requisitos instrumentais da participação e do controle social da administração pública, as seguintes:

(a) a exigência de publicidade dos atos da Administração, para os fins de garantir um grau de visibilidade do poder político e social, dela não podendo constar nomes, símbolos ou imagens que caracterizem promoção pessoal de autoridades ou servidores públicos ${ }^{51}$, ao mesmo tempo em que se impõe como requisito de vigência da norma legal ${ }^{52}$;

(b) o direito do cidadão em obter certidões do Poder Público, visando trazer informações oficiais sobre interesses pessoais e determinados, consoante disposição constitucional inscrita no art. $5^{\circ}$, inciso XXXIV, do mesmo Estatuto;

(c) o direito de petição, garantido a qualquer pessoa, independentemente de ser ou não cidadão, alcançando aos três poderes do Estado, para os fins de defesa de direitos ou contra ilegalidade ou abuso de poder, nos termos do art. $5^{\circ}$, inciso XXXIV, a.

Por tais argumentos é que o Segredo de Estado não tem vez nos regimes democráticos contemporâneos, sendo até possível, em raríssimas e muito bem justificadas situações, aceitar-se a existência da informação e do documento secreto não mais reportado à posição do seu detentor, mas à qualidade da informação/documento envolvido e o que protege, superando-se, desta maneira, o fundamento meramente subjetivo e pessoal do segredo administrativo - um documento é segredo porque pertence à Administração Pública, ou porque o Administrador assim o entende -; mas pelo fato de representar uma concessão objetiva e real (tal documento/informação é segredo em face da qualidade da informação que contém, justificado normativa e racionalmente).

Pode-se imaginar, no ponto, a situação do art. 50, inciso XXXIII, da CF/88, ao disciplinar que todos têm direito a receber dos órgãos públicos informações de seu interesse particular, ou de interesse coletivo ou geral, que serão prestadas no prazo da lei, sob pena de responsabilidade, ressalvadas aquelas cujo sigilo seja imprescindível à segurança da sociedade e do Estado. ${ }^{53}$

\footnotetext{
${ }^{51}$ Nos termos do art. 37, caput e parágrafo primeiro, da CF/88, destacando-se este publicidade como princípio informativo da própria Administração Pública.

${ }^{52}$ Cumpre destacar que a publicidade, neste particular, não é elemento formativo do ato, necessário a existência válida deste ato, salvo quando a lei o dispuser, mas será sempre requisito de sua eficácia, exequibilidade e de sua moralidade. Neste sentido, ver o texto de MOREIRA NETO, Diogo de Figueiredo. Direito de Participação Política. Rio de Janeiro: Renovar, 1993, p. 107 e ss.

${ }^{53}$ Alia-se a isto o disposto no art. $37, \S 3^{\circ}$, da CF/88, ao dispor que a lei disciplinará as formas de participação do usuário na administração pública direta e indireta, regulando especialmente: II - o acesso dos usuários a registros administrativos e a informações sobre atos de governo; mais o art. 216, $\S 2^{\circ}$, estabelecendo que cabem à administração pública, na forma da lei, a gestão da documentação governamental e as providências para franquear sua consulta a quantos dela necessitem.
} 
Mas, afinal, quais são as informações cujo sigilo seja imprescindível à segurança da Sociedade e do Estado? Quem define, e como o faz, os critérios de eleição desta imprescindibilidade? De que tipo de segurança se está falando aqui em face da Sociedade e do Estado? Estas questões demandam reflexão e respostas preliminares.

Aquela disposição do art. 50, inciso XXXIII, da CF/88, acima referida, veio ratificada pelos termos da Lei Federal $n^{\circ} 8.159 / 91$, em especial no seu art. $4^{\circ}$, repetindo praticamente a dicção constitucional, assim como o fez os termos do art. $2^{\circ}$, da Lei Federal $n^{\circ} 11.111 / 2005$, que regulamentou a parte final deste inciso da Carta Política. Ocorre que ambas as normas federais restringiram o acesso a dados, documentos e informações que envolvem o período militar.

O problema é que a Lei Federal $n^{\circ} 11.111 / 2005$, criou uma forma nada Republicana e Democrática de identificação e catalogamento do que sejam documentos, dados e informações que demandam o chamado Segredo de Estado, ao afirmar em seu art. $4^{\circ}$ que: O Poder Executivo instituirá, no âmbito da Casa Civil da Presidência da República, Comissão de Averiguação e Análise de Informações Sigilosas, com a finalidade de decidir sobre a aplicação da ressalva ao acesso de documentos. Pergunta-se: qual a legitimidade democrática que tem o Poder Executivo para deliberar, desta forma monológica, sobre o acesso de informações que interessa a toda a Sociedade e à Democracia?

Não bastasse isto, ainda fez mais a referida Lei, pois em seu art. $5^{\circ}$ expandiu de forma absurda aquela competência, ao referir que: Os Poderes Legislativo e Judiciário, o Ministério Público da União e o Tribunal de Contas da União disciplinarão internamente sobre a necessidade de manutenção da proteção das informações por eles produzidas, cujo sigilo seja imprescindível à segurança da sociedade e do Estado, bem como a possibilidade de seu acesso quando cessar essa necessidade. Bem, agora sim todas as portas foram fechadas à Sociedade e mesmo às pessoas diretamente atingidas que queiram saber informações sobre os fatos ocorridos no regime ditatorial. ${ }^{54}$

\footnotetext{
${ }^{54}$ O projeto de Lei Federal $n^{\circ} 41 / 2010$, por incrível que pareça, ainda piora esta situação ao determinar que: Art. 27. A classificação do sigilo de informações no âmbito da administração pública federal é de competência: I - no grau de ultrassecreto, das seguintes autoridades: a) Presidente da República; b) Vice-Presidente da República; c) Ministros de Estado e autoridades com as mesmas prerrogativas; d) Comandantes da Marinha, do Exército e da Aeronáutica; e e) Chefes de Missões Diplomáticas e Consulares permanentes no exterior; II - no grau de secreto, das autoridades referidas no inciso I, dos titulares de autarquias, fundações ou empresas públicas e sociedades de economia mista; e III - no grau de reservado, das autoridades referidas nos incisos I e II e das que exerçam funções de direção, comando ou chefia, de hierarquia equivalente ou superior ao nível DAS 101.5, do Grupo-Direção e Assessoramento Superiores, de acordo com regulamentação específica de cada órgão ou entidade, observado o disposto nesta Lei. $\S 1^{\circ} \mathrm{A}$ competência prevista nos incisos I e II, no que se refere à classificação como ultrassecreta e secreta, poderá ser delegada pela autoridade responsável a agente público, inclusive em missão no exterior, vedada a subdelegação. Grifos meus.
} 
É jurídica e politicamente aceitável esta restrição de Direito Constitucional Fundamental que estabelecem tais normativas federais, notadamente em face de que, pelos termos do art. 24, da Lei Federal no 8.159/91, poderá o Poder Judiciário, em qualquer instância, determinar a exibição reservada de qualquer documento sigiloso, sempre que indispensável à defesa de direito próprio ou esclarecimento de situação pessoal da parte? Ademais, nenhuma norma de organização administrativa será interpretada de modo a, por qualquer forma, restringir o disposto neste artigo. ${ }^{55}$

Como resolver esta antinomia direta/indireta existente aqui?

O projeto de Lei Federal $n^{\circ} 41 / 2010$, que tramita no Congresso Nacional, em seus arts. 23 e 24, tenta demarcar de forma mais objetiva e pontual quais seriam os temas e, por consequência, documentos, informações e dados, que se submeteriam ao regime de segurança de Estado e, portanto, com restrição de acesso. Esta mesma normativa prevê, em seu art. $5^{\circ}$, que é dever do Estado garantir o direito de acesso à informação, que será franqueada, mediante procedimentos objetivos e ágeis, de forma transparente, clara e em linguagem de fácil compreensão. Ainda mais, no $\S 5^{\circ}$, do art. 24, diz claramente que: para a classificação da informação em determinado grau de sigilo, deverá ser observado o interesse público da informação, e utilizado o critério menos restritivo possível, considerados, dentre outros elementos, a gravidade do risco ou dano à segurança da sociedade e do Estado, portanto, mister é que se façam juízos de valor justificatórios e fundamentalizantes na decisão sobre a restrição imposta, já que a diretriz para tanto é utilizar o critério menos restritivel possível, exatamente para privilegiar o direito de acesso.

$\mathrm{E}$ por que isto? Pelo fato de que questões condizentes a direitos constitucionais fundamentais não pertencem simplesmente a uma área particular do direito, pois as respostas decorrentes delas têm consequências em toda a estrutura do sistema jurídico e mesmo social. ${ }^{56}$

O que se tem de ter em mente, a partir do referido, é que, por mais que a norma constitucional estabeleça catálogos de direitos e garantias constitucionais referidas como auto-aplicáveis, e disto não se tem dúvidas, o fenômeno de efetivação concretizante destes sempre contará com graus/medidas passíveis de mensuração, e estas, definitivamente, não estão

${ }^{55}$ No art. 25, da Lei, tem-se a advertência de que: Ficará sujeito à responsabilidade penal, civil e administrativa, na forma da legislação em vigor, aquele que desfigurar ou destruir documentos de valor permanente ou considerado como de interesse público e social.

${ }^{56}$ Conforme ALEXY, Robert. The Construction of Constitutional Rights. In Law \& Ethics of Human Rights, Volume 4, Issue 1. Article 2. Berkeley: Berkeley Electronic Press, 2010. Nas palavras do autor: Questions pertaining to constitutional rights are not simply questions in a particular area of law. The answers given to such questions have consequences for the structure of the entire legal system. The spectrum extends from the third party or horizontal effect, that is, the bearing of constitutional rights on private law, right up to the relation between the legislature and the practice of constitutional review, behind which the tension between constitutional rights and democracy is found. (p. 03).

DiREITOS FundAMENTAIS E JUSTIÇA - ANO 6, N' 18, P. 203-228, JAN./MAR. 2012 
dadas pela Carta Política, demandando do intérprete/aplicador atribuição de sentido racional e material às suas reivindicações, caso por caso (que inclusive pode tratar de interesse coletivo, difuso ou individual homogêneo), levando em conta o universo de variáveis que convergem a ele.

\section{CONSIDERAÇÕES FINAIS}

Não são simples as decorrências conceituais e operacionais da ideia de verdade que estou trabalhando aqui, tanto em face dos elementos materiais e simbólicos que se ocupa, como em razão da perspectiva teleológica que entendo devam ter às gerações presentes e futuras.

As questões que dizem respeito a temas como estes são sempre traumáticos e potencialmente danosos, pelo simples fato de tratarem de matérias que recordam um tempo que a maior parte da população ou sequer conheceu, ou não quiseram conhecer, ou ainda desejam esquecer.

Penso que o segredo e o silêncio da Administração Pública sobre tais assuntos têm contribuído em muito para provocar uma amnésia irresponsável em nível de cidadania, como se a passagem do tempo tivesse o condão de apagar da vida das pessoas os vestígios indeléveis que causou em vidas humanas e, com isto, autorizar o esquecimento e o desconhecimento.

Ocorre que este esquecimento ou falta de conhecimento se dão sobre interesses públicos indisponíveis, porque atinentes a Direitos Fundamentais da pessoa humana que foram violados, tanto física como simbolicamente, e por isto precisam vir à tona para cumprir seu papel civilizatório de compromisso à Democracia.

O Brasil precisa cumprir com o dever institucional de providenciar o conhecimento público dos fatos e documentos que detém à Sociedade, independentemente das intenções daqueles que estão na posse deste material todo, fazendo deles ferramentas cívicas de aprendizado político e histórico, para que não se repita o ocorrido nas gerações presentes e futuras.

O problema é que tão importante quanto a decisão política e institucional de instituir uma Comissão da Verdade é viabilizá-la eficazmente em termos operacionais e de resultados, sob pena de esvaziamento teleológico dos seus objetivos, por tais razões é que o debate internacional tem sugerido algumas estratégias metodológicas de procedimentos destes órgãos, a saber:

(1) Em termos de mandato e faculdades, o objetivo principal é o esclarecimento da verdade, contribuindo para a reconciliação nacional, formulando recomendações para auxiliar as vítimas e prevenir o retorno a um regime autoritário.

(2) No que tange à composição, as pessoas selecionadas determinam, em grande parte, o êxito ou não destas Comissões, razão pela qual devem ser bem escolhidas levando em conta o perfil, a notoriedade nacional e internacional, a capacidade de articulação e de produzir resultados, a formatação de redes de cooperação, talvez até com a contribuição de componentes internacionais, o que gera credibilidade para com todos. 
(3) É preciso ter estratégias de comunicação, para que todo o trabalho desenvolvido pela Comissão seja público ou publicizado, com reuniões de divulgação, publicações, vídeos, a fim de confirmar sua credibilidade.

(4) É fundamental constituir mecanismos adequados de recepção de testemunhos, pois a maior parte das informações são recebidas através deles, mediante reuniões privadas. Para as vítimas e testemunhas aqueles que os ouvem serão o único contato com a Comissão, razão pela qual devem causar boa impressão, dando a atenção devida e merecida a todos.

(5) A investigação realizada pela Comissão tem de gerar uma base de dados efetiva para o armazenamento de todos os elementos colhidos durante o período de suas atividades.

(6) Revela-se igualmente producente a realização de Audiências públicas para o tratamento da matéria, gerando não só o reconhecimento público do ocorrido e das providências que devem ser tomadas a respeito, bem como a oportunidade das vítimas e violadores contarem sua história.

(7) A Comissão da Verdade vai, ao fim e ao cabo, produzir informes finais, que se converterão em fonte à educação sobre Direitos Humanos e Fundamentais. Esses informes, se bem documentados e baseados em uma metodologia adequada, podem servir como proteção contra distorções da história e como ferramentas de educação popular e formal em todos os níveis da República. ${ }^{57}$

Recentemente, em outra medida governamental, o Ministério da Justiça resolveu assegurar o acesso a arquivos e documentos envolvendo os atos de sequestro, morte, desaparecimento e tortura de pessoas no período do regime militar a familiares dos atingidos. ${ }^{58}$

Os debates internacionais - em especial - tem orientado para o fato de que cada processo de transição é único e varia com o contexto cultural e histórico de onde ele opera, levando em conta: as variáveis de vontade política das autoridades e da sociedade civil para encarar a reconciliação; também variam as capacidades e os recursos empregados pelas instituições públicas para tal desiderato; o fato de que a reconciliação duradoura deve ter raízes em processos locais, pois só as vítimas e os perpetradores podem reconciliar-se entre si; que as atividades de reconciliação demandam tempo, anos ou décadas, sendo requisito fundamental a adequação do tempo para as ações de reconciliação e mesmo da Comissão da Verdade. ${ }^{59}$

Há muito ainda o que discutir.

${ }^{57}$ INSTITUTO INTERAMERICANO DE DIREITOS HUMANOS. Verdad, Justicia y Reparación: Desafíos para la democracia y la convivencia social. Op.cit., p. 49.

${ }^{58}$ In www.oglobo.com.br, acessado em 24.07.2011.

${ }^{59}$ Idem, p. 54. Para além disto, cabe aqui a advertência de há uma diferença entre reconciliação 'política' e reconciliação 'social', a primeira pode ser realizada através de acordo entre elites, porém, a segunda, poderá jamais ficar completa. In MANDANI, Madmood. Reconciliation without Justice. Southern African Review of Books, 10 (6), 1996, acessado em www.ilam.org, acessado em 25.07.2011.

DiREITOS FundAMENTAIS E JUSTIÇA - ANO 6, N' 18, P. 203-228, JAN./MAR. 2012 


\section{REFERÊNCIAS}

ALCHOURRÓN, Carlo. Sistemi Normativi. Introduzione alla Metodologia della Scienza Giuridica. Torino: Giappichelli, 2009.

ALEXY, Robert. Teoria da Argumentação Jurídica: a teoria do discurso racional como teoria da justificação jurídica. São Paulo: Landy, 2001.

. Teoría de los Derechos Fundamentales. Madrid: Centros de Estudios Constitucionales, 2000.

The Construction of Constitutional Rights. In Law \& Ethics of Human Rights,

$\overline{\text { Volume }} 4$, Issue 1. Article 2. Berkeley: Berkeley Electronic Press, 2010.

ANDRONICO, Alberto. Ermeneutica e diritto da Wilhelm Dilthey ed Emilio Betti. In Spicchi di Novecento, a cura di Bruno Montanari. Roma: Giappichelli, 2008.

ANNUAL REPORTS OF IACHR, 1985-1986.

ARENA, Gregório. I/ Segreto Amministrativo. Padova: CEDAM, 2004.

ARENDT, Hannah. De la Historia a la Acción. Barcelona: Paidós, 1995.

ASMAL, Kader. International Law and Practice: dealing whit the past in the South African experience. In International Law Review, vol. 15, nº 06, nov. 2000, p. 1215.

AVRITZER, Leonardo. Teoria Democrática, Esfera Pública e Participação Local. In Revista Sociologias, ano 1, nº 2, jul./dez. de 1999. Porto Alegre: UFGRS, 1999.

AZOCAR, Patrício Aylwin. La Comisión de la Verdad y Reconciliación de Chile. In http://www.bibliojuridica.org/libros/4/1836/8.pdf, acesso em 27.05.2011.

BORAINE, Alex. What price reconciliation? The achievement of the TRC. In A Country Unmasked. Oxford: Oxford University Press, 2000.

BRUGALETTA, Francesco. Poteri Pubblici e Dovere di Disseminazione: I'altra faccia del diritto all'informazione. In Rivista Diritto \& Diritti, www.diritto\&diritti.com.it, acessada em 06.04.2011.

BUNCHAFT, Maria Eugenia. Patriotismo Constitucional na perspectiva de Jürgen Habermas. Rio de Janeiro: Lúmen Júris, 2010.

DELLA TORRE, Zucchetti. Privacy e Accesso ai Documenti Amministrativi. Roma: Giuffrè, 2009.

DICIOTTI, Marco. Interpretazione della Legge e Discorso Razionale. Roma: Laterza, 2010.

DWORKIN, Ronald. Is Democracy possible here? Principles for a New Political Debate. Princeton: Princeton University Press, 2006.

DYZENHAUS, David. Judging the Judges, Judging Ourselves: Truth, Reconciliation and the Apartheid Legal Order, Oxford: Hart Publishing, 1998.

FALK, Richard. On Humane Governance: toward a new global politics. Cambridge: Polity, 2006.

HABERMAS, Jürgen. Direito e Democracia: entre faticidade e validade. v. I e II. Rio de Janeiro: Tempo Brasileiro, 1997.

Teoria de la Acción Comunicativa. Vol. I e II. Madrid: Taurus, 1999.

HAYNER, Priscilla. Unspeakable Truths: Confronting State Terror and Atrocity. New York: Routledge, 2008.

http://noticias.terra.com.br/brasil/noticias/Pedro+Simon+defende+divulgacao+de+documentos +secretos.html, acessado em 15.06.2011, e publicado em 14.06.2011. 
http://oglobo.globo.com/pais/mat/2011/06/14/sobre-documentos-secretos-sarney-diz-quenao-se-pode-fazer-wikileaks-da-historia-do-brasil-924680159.asp, acessado em 14.01.2006. http://pbrasil.wordpress.com/2009/10/28/representantes-de-exercitos-americanos-se-reunemna-argentina, acesso em 14.06.2011.

http://www.bolpress.com/art.php?Cod=2009072206, acessado em 03.06.2011.

http://www.desaparecidos.org/arg/conadep/nuncamas/, acesso em 25.05.2011.

http://www.educabolivia.bo/educabolivia, acessado em 03.06.2011.

http://www.mercosur.int/msweb/Documentos/Publicados/Comunicaciones, acessado em 03.06.2011.

http://www.sgex.eb.mil.br/qgnoticias/qgex_352.pdf, acessada em 14.06.2011.

http://www.uca.edu.sv/publica/idhuca/cv.pdf, acessado em 03.06.2011.

INSTITUTE. International Human Rights Law. Los Principios de Chicago sobre Justicia transicional. In http://www.iidh.ed.cr/bibliotecadigital, acesso em 29.01.2011.

INSTITUTO DE DERECHOS HUMANOS DE LA UNIVERSIDAD CENTROAMERICANA JOSÉ SIMEÓN CAÑAS. La agenda pendiente, diez años después (de la esperanza inicial a las responsabilidades compartidas). EI Salvador: UCA, Noviembre de 2002.

INSTITUTO INTERAMERICANO DE DIREITOS HUMANOS. Verdad, Justicia $y$ Reparación: Desafíos para la democracia y la convivencia social. Disponível em: www.iidh.ed.cr. Acesso em: 27.05.2011.

KISS, Elizabeth. Moral Ambitions Within and Beyond Political Constraint: reflexions on restorative justice. New York: Lendell, 2007.

LEAL, Rogério Gesta. Condições e Possibilidades Eficaciais dos Direitos Fundamentais Sociais: os desafios do Poder Judiciário no Brasil. Porto Alegre: Livraria do Advogado, 2009.

. Estado, Administração Pública e Sociedade: novos paradigmas. Porto Alegre: Livraria do Advogado, 2008.

MACPHERSON, C.B. La Democracia Liberal y su época. Madrid: Alianza Editorial S.A., 1977.

. Ascensão e Queda da Justiça Econômica. São Paulo: Paz e Terra, 1991.

1979.

A Teoria Política do Individualismo Possessivo. Rio de Janeiro: Paz e Terra,

MADARIAGA, Carlos. La Reparación por parte del Estado hacia las víctimas de la Tortura. In Revista Reflexión, año 7, n² 22. Diciembro de 1994. Santiago: Chile, 1994.

MANDANI, Madmood. Reconciliation without Justice. In Southern African Review of Books, 10 (6), 1996, acessado em www.ilam.org, acessado em 25.07.2011.

MCGOLDRICK, Dominic. The Human Rights Committee - Its role in the development of the International Covenant on Civil and Political Rights. Oxford: Oxford University Press, 2006.

MÉNDEZ, Juan. Accountability for past Abuses. In Human Rights Quarterly, vol. 19, $\mathrm{n}^{\circ} 2$, May 1997.

NACIONES UNIDAS, COMISIÓN DE DERECHOS HUMANOS. Informe del Alto Comisionado de las Naciones Unidas para los Derechos Humanos sobre la situación de los derechos humanos en Colombia, E/CN.4/2003/13, 24 de febrero de 2003.

DiREITOS FundAMENTAIS E JUSTIÇA - ANo 6, N 18, P. 203-228, JAN./MAR. 2012 
NACIONES UNIDAS. COMISIÓN DE DERECHOS HUMANOS. Promoción y Protección de los Derechos Humanos. Estudio sobre el Derecho a la Verdad. In E/CN.4/2006/91, 09 de enero de 2006, 62 ${ }^{\circ}$ período de sesiones. Tema 17 del programa provisional, 2006. NÜRNBERGER, Esteban Cuya. Las Comisiones de la verdad en América Latina. Disponível em: http://www.iidh.ed.cr/bibliotecadigital. Acesso em 29.01.2011.

O'DONNELL, Guillermo; SCHMITTER, Paul; WHITEHEAD, Louis (eds.). Transitions from Authoritarian Rule. 4 Vols., Baltimore: Johns Hopkins University Press, 1986.

OIGA, "Informe sobre Uchuraccay", Lima, Perú, 7 de marzo de 1983.

ORESTANO, Ricardo. Sulla Problemática del Segreto. Roma: Mulino, 2009.

PÁEZ, D.; VALENCIA, J.; PENNEBAKER, J.; RIMÉ, B.; JODELET, D. (EDS); Memoria Colectiva de Procesos Culturales y Políticos. Editorial de la Universidad del País Vasco/Euskal Herriko Unibertsitatea, Leioa, 1997.

RAWLS, John. A Theory of Justice. Cambridge: Harvard University Press, 1971.

ROMANO, Santi. Principii di Diritto Amministrativo. Milano: Giuffrè, 1906.

SCHAUER, Frederick Le Regole del Gioco. Un'analisi Filosofica delle Decisioni prese Secondo regole nel Diritto e nella vita quotidiana. Bologna: II Mulino, 2009.

. Balancing, Subsumption, and the Constraining Role of Legal Text. In Law \& Ethics of Human Rights Review, vol. 4, Issue 1. Berkeley: Berkeley Electronic Press, 2010, http://www.bepress.com/lehr/vol4/iss1/art3, acessado em 09.12.2010.

STARR, Paul. Liberalism for Now. In www.nybooks.com/articles, Volume 56, $\mathrm{n}^{\circ} 12$, julho de 2009, acessado em 10.02.2010.

TAVUCHIS, Nicholas. Mea Culpa: a sociology of apology and reconciliation. Stanford: Stanford University Press, 2001.

TEITEL, Ruti G. Genealogía de la Justicia Transicional. In http://www.iidh.ed.cr/bibliotecadigital, acesso em 29.01.2011.

TOIT, Andrè du. Los Fundamentos Morales de las Comisiones de Verdad la Verdad como Reconocimiento y la Justicia como Recognition: Principios de la Justicia Transicional en la Práctica de la Comisión de Verdad y Reconciliación (CVR) Sudafricana. Centro de Derechos Humanos, Facultad de Derecho, Universidad de Chile, 2008.

VIROLI, Maurizio. For love of Country. An essay on patriotism and nationalism. Oxford: Clarendon Press, 1995. 